Namazova S., $P h D$,

\title{
DEVELOPMENT OF THE LITERARY THROUGHT IN THE PERIOD OF AZERBAIJAN DEMOCRATIC REPUBLIC
}

Summary. During the period of the Azerbaijan Democratic Republic, the problem of national unity and moral integrity was socio-political importance for our people, this crucial issue has been clarified consistently in diverse genre and content literary works by various artisan. The poetry of the period of the Azerbaijan Democratic Republic was fully relating with the ideas of freedom, and served directly to the national awakening of the people. David, a talanted poet who has little familar for the readers with his works. "Our Purpose", "The song of the Solider", "A Solider's address", "For the Army of Azerbaijan", "Fathers", "My nation" and etc. in these poems he described by lines the joys that independence brought the people's lifes. His poems were written mainly in sharki genres adressed to the youngs, so in the language of youngs. Publicity branch of the literary creativity was distinguished with its productivity in comparison with the literary prose in the period of Azebaijan Democratic Republic. So, Jalil Mammadguluzadeh's, "Azerbaijan" (1917), "The Republic" (1917), "The Citizens" and in the other publicist writings were focused attention on number of socio-political issues. Leading the development of national thought independent sipirt writings, also publicist samples consecutive publishing in various presses were payed attention specially in the period of Azerbaijan Democratic Republic. In short, the people's struggle for freedom was expanding. In this regard, there was a need for greater using of the possibilities of expression of the publicist word. Reflecting a number of aspects of sociopolitical life of the early XX century, describing the tragedy with the capacity of literary expression that occured to our nation Seid Hussein's documentary stories "Ismailia", and "A melancholy memory", also attack the attention according to its subject. In the "Ismailia" story, which founded on the autor's speech was dealt with heartache burning of the great, famous Ismailia building by armenians. The dramatic works written during the period of Democratic Republic were not so much as samples of literary prose. That's right dramatic works clarifing some opportunities of that historical period works were created. So, dramatic creativities of Jalil Mammadguluzadeh, Hussein Javid, Jafar Jabbarli, Mirzabala Mahammadzadeh attact more attention in this regard. So the works of Jalil Mammadguluzadeh's "Kamancha", "My Mother's book" Hussein Javid's "Nasraddin Shah", "Edirne's conguest", "Trablis War or the Star" and "Aydin" express in detail the view of the dramatics of that time.

Key words: Democratic Republican period, literary process, literary prose, poetry, publicity.

Introduction. The idea of a republic, the awakening of national consciousness in the modern sense in Azerbaijan, has gained wide popularity at the end of the XIX century. Most of the historical figures representing that time Hasan bey Zardabi, Ali bey Husseinzadeh, Ahmed bey Agaoglu, Nariman Narimanov, Jalil Mammadguluzadeh,
Mohammad Hadi, Hussein Javid, Mirza Alekber Sabir, Abdulla Shaig, they were connected closely with the press, which was the basis for formating of cultural thinking. On the other hand, also connect of Azerbaijan Democratic Republic with the presses that "Hayat" and "Fujuzat" was proved when "Hayatchilar", "Fujuzatchilar" (M. A. Rasulzadeh, A. Topchubashov, M. Hajinski, A.K. Agaoglu, A. Husseinzadeh etc.) subsequently joined the government of the republic or participated closely in its activities" [5, p. 466]

Forming of the literary figurative process were Mammad Amin Rasulzadeh, Mirzabala Mohammadzadeh, Deputy Speaker of the Parliament Ahmad bay Agaoglu, Speaker of the Parliament Alimardan bay Topchubasov, Uzeir Hajibayli, Ali Huseinzadeh, Aliabas Musnib, Salman Mumtaz and many others in the period of Azerbaijan Democratic Republic. Especially, Ahmad Jawad "poet of republic", Aliusif Rai, Umgulsum Sadigzadeh, Amin Abid, Jafar Jabbarli, David Ganjali, Abid, Jafar Jabbarli, and Ali Shawgi, the poems of such talanted writers characterized by the call for national struggle, was widespread among the people.

Forming of the literary process in the period of the Azerbaijan Democratic Republic. Plural successes was got in poetry in comparison with the other directions of literary through in the period of Democratic Republic. That was due to the fact that the proety was more dynamic, versatile, variety in genre.

In those years literary examples written by powerful writers such as Mohammed Hadi, Hussein Javid, Abdullah Shaig, Jafar Jabbarli, Ahmad Javad, Umgulsum Sadigzadeh, and others reflected clearly independence spirits of the period.

"Azerbaijan", "Goygol", "Our main ideology", and "Dedication to the honor of our heroism", "Musavat's anthem", "Burning Voice of Motherland", "My Mother's Book", "Kamancha", "The Sun of freedom ", "The Flag of Azerbaijan", "Sheida", "Aydin", "War for Baku", "Fructured wing", "A memorial Ismailiyya, "Blessing", "Unluckly persons","The Consul's wife", "A Look at Azerbaijani Literature". "Feature storys about The History of Azerbaijani Literature", Wreath of Turkish" and etc. The works that were written in the most different genre and content were valuable samples in the period of Azerbaijan Democratic Republic.

In the period of Azerbaijan Democratic Republic Abdullah Shaig dedicated a poem to the Musavat party which was leadership Mammad Amin Rasulzadeh and this poetic sample even became the anthem of the "Musavat". Let's pay attention the lines from the poet that dedicated to "Musavat", the "Turkish literary central group".

Let's unite Turkish, this way is the nation's way

Our history is full with fame, glory, gilt

Let's go forward, solider of the nation,

Your past is glory, triumph, let's don't go back

Your bright eyes are weep bitterly to the enemy. 
In addition, another fact expressing Abdulla Shaig's love for Musavat and the Azerbaijan Democratic Republic is his participation in "Achig Soz", "Azerbaijan" newspapers, which is directly Musavat's organ. [6, p. 83]

In the Democratic Republic, Ummugulsum Sadigzadeh's creativity according to be productive was differentiate, and was appreciated. Her "Turan's fife", "Hey Turkish son", "Let’s vote", "Go, Get away", "The Soldier's mother", "I waited your way", "On May this year", "For a girl" and so on. the poems attract the attention with being diverse according to genre and theme, also expression of their sentiments for national awakening. In the poem "Turan's fife", showed that a poetess was trying to promote the ideas of Turkism and Turanism and he had seen the liberation of the Turks only in this way.

They destroy the nest of nightingale,

Leaves of every flower fell in autumn.

They made keep silence song of a country

Where is a lover giving a life the sweetheart?

Aliyusuf's "For the Azerbaijani", "The flag", "Ideal", "Don't go", "A turkish traveler says..", "For Karabakh traitors", Jalal Sahir "Caucasian turku" (Turku is Turkish folk music) "Azerbaijan" by Mohammad Umid Ganjali, "From the language of a wounded soldier" by Abdurrahman Dain and others poems according to content reflected clearly the spirit of the period. Ali Yusif was one of the most talented poets who welcomed Azerbaijan's independence with the gladness. As in the poem addressed to "Azerbaijan".

Hey citizen, today is your destiny

A star that gives light to the conscience is born.

Hey Caucasian from your magnificent creature

The star is born that will never be extinguished

The star that humanity blood was shed for it,

In its history as the rivers

Davud's "Our goal", "Soldier's song" "One Soldier's address", "Azerbaijani army", "To my nation", etc. in the poems were described the joys that independence presented the people's lives, "The address of a solider" is typical in this regard.

I am going to army, mother, why are you crying?

Why are you burning heart of a soldier, mother?

I am a sentinel with arm for my motherland in the borders,

I am a sentinel for my honor, for my nation and for you [3].

At the beginning of the XX century, publicity was more prominent than the literary prose. In spite of this, a number of prose examples reflecting the spirit of the period also emerged, illuminated on various aspects of people's lives.

Representatives of different literary generations in the years of Democratic Republic have worked hard in the branch of figurative prose, and have written remarkable examples of creativity. The stories of Jalil Mammadguluzadeh, "Wonderfulness", "Consul's Wife", "Khan's beads" and Abdurrahim bay Hagverdiyev's "The Poets" stories which later introduced the readers as "Mirza Safar" including Said Hussein's "A Melancholy Memories" and "Ismailia" are literary examples that is very interesting for the readers.

From this point of view, Jafar Jabbarli's story "From Parapet to Shamakhi" which wrote in the period of Azerbaijan Democratic Republic was distinguished by its satirical- humorous spirit. In the story dealt with the adventures of the employees of the newspaper "Azerbaijan" in rainy weather. Also activity of the city administration was severely criticized in the work .

At the same time,Abdullah Shaig wrotea part of the novel "Heroes of Our Century" during the Democratic Republic. Considering one of the most successful examples of the novel in the Azerbaijani literature, was concentrated the World War I, collapsing of the Tsarist Russia, and the problems that thinking delegations of the new generation.

Period of the Republican was chosen the object of research in the Abbas Sahhat's story "Luckless Halima" too. Here was dealt with the tragedies that World War I brought on families. In the work is show that Halima, whose home is burned, loses her son after the death of his husband, Haji Nuru, segregates from her daughter, and confronts series tragedies. Then Halima go to Anatolia, meets her daughter Zeynab there. Finally, the separation of many years comes to an end, and the mother and daughter reunites.

"A Melancholy memories", and "Ismailia" were written by Said Hussein, in both the documentary stories were dealt with after burning this magnificent building by Armenians and describing next painful fate after destroying, the events of that time has commented with particular accuracy by the writer.

In his second documentary story Ismailia, Said Hussein describes the events that take place during the March genocide. "What a pity, Ismailia was burned, its ceiling was destroyed. A faint smoke coming out from inside without exaggeration, I have never been so impressed in my life. Disappointed, I wandered around the four corners. I entered inside. I sat down on the tassel and started to think about it. I thought, I looked through the thunderous meeting and counseling struggles which was organized there, and I judged about different organizations that haven't got any auspices now. I said myself.

Neither the "Musavat" bureau nor the "Hummat", "Muslim" and so on. parties and organizations. It's only the building of Ismailia that burning treacherously" [4].

In the story, the writer who continues the speech also emphasize that;

"Do you know what is the reality that proves the world Ismailia could not be burnt? Azerbaijani flag for three-colored and eightpointed star shaped engraving on the Azerbaijani Parliament" [4].

An important factor in the advancement of society accelerating the literary process, of course, is widespread allocation of press and publicity in the creative sphere. From time to time this factor has played an important role in the formation of public, political, and figurative thought in the country, and it's true purpose consist of directing national thinking.

The people's public opinion, their outlooks on life their attitude towards social-public and cultural processes have become clearly only in publicity. Azerbaijan publicity also attacked attention with intervening operatively the sociopolitical events of the early XX century, the difference of theme and the richness of the genre.

It's clearly that the social and political factors of the time required to become more important the publicity as a creation branch. In this regard, also publicity of the Democratic Republican period was distinguished with the variety of subject, wide of the theme sphere and its versatility. So, at that time, in "Azerbaijan, "Istiglal", "Ittihad", "El", "Dogru yol", "Millat", "Maktab", "Turk sozu", "Basirat", "Achig soz", "Ovragi-nafisa", "Gurtulush" and other. press published a number of publications that affect public opinion. The main themes that reflected people's lives, feelings, thoughts and experiences clarified adequately in journalism of the period. Concentrating features that cause the people's national self determination, most presses times was staying as a major subject at that times. 
The samples of publicity of the period were published in the presses mainly "Azerbaijan", "Istiglal", "Basirat", "Achig soz", "Ovragi- nafsi", "Gurtulush" and others. Uzeir Hajibayli, Mohammed Amin Rasulzadeh, Mohammad aga Shahtakhtli, Yusif Vazir Chamanzaminli, Sayyid Hussein and other's publicist creativity besides being new according to content and form has been related closely the most important events of the time. The announcement of national independence, the Caucasus Islamic Army's rescuing mission in Azerbaijan, calling for defense spirit against crafty intention of enemy from both inside and outside the country, issues that was done in the branch of education and culture was focused on themes in the period of Democratic Republic.

So, M. Rasulzadeh's "The Capital of Azerbaijan", "Day of Salvation" "The Day of Righteousness", "Unforgettable tragedy", U. Hajibayli's "Necessary problems", "Denkins near us", A. Javad's "Hearsays", "Denkin and Ganja", "Rovshan Ashraf bay" "Consultation with the Minister of Internal Affairs" M. Hadi's "Impact of the revelution", "On account of two political men's ideas about war" "Live with hope", "Abbas Sahhat's ufuliabadisi", Y. V. Chamanzaminli's articles "Our National and Cultural Works", "Our foreign politics" and etc. are interesting samples of in the period of Democratic Republic.

Conclusions. Accompanied by the strengthening of national self-expression processes, the promotion of the ideas of patriotism, Azerbaijani publicity achieved progress aspects of opportunity content and creativity.

In this aspect, periodical press was sitting in the forefront of ideological struggle in Azerbaijan in 1918-1920, national journalism was enriching from aspect topic and ideas, and has been boldly touched on various content articles about the seriousness of the future of the nation. From this point of view, the idea that "one of the most powerful factors in the development of social and cultural renaissance of the Azerbaijani Turkic origin was press" is absolutely right. Also the press has played an important role in the formation of socio-political and literary and figurative thinking in the Azerbaijan Democratic Republic, and the public was guided to the people by means of sharp guns.

\section{References:}

1. "Achiq Soz" newspaper, February 6, 1918.

2. “Azerbaijan" newspaper, 1918.

3. “Azerbaijan" newspaper, January 6, 1920.

4. "Istiglal" newspaper, February 4, 1920.

5. Garayev Y. Azerbaijan literature of the 19th and 20 th centuries. Baku; Science, 2002, 740 pages.

6. A. Saracli Azerbaijani writers are in the Republic. Baku 2007.
Намазова С. Розвиток літературної суті в період Азербайджанської Демократичної Республіки

Анотація. У період Азербайджанської Демократичної Республіки проблема національної єдності та моральної цілісності мала суспільно-політичне значення для нашого народу, це вирішальне питання послідовно з'ясовувалось у різноманітних жанрових та змістових літературних творах різних майстрів. Поезія періоду Азербайджанської Демократичної Республіки повністю відповідала ідеям свободи і служила безпосередньо національному пробудженню народу. Девід, талановитий поет, мало знайомий читачам своїми творами. «Наша мета», «Пісня Солідера», «Адреса Солідера», «Для армії Азербайджану», «Отців», «Моя нація» тощо. У цих віршах він описав рядками радощі, які незалежність принесла людям. Його вірші були написані переважно в жанрах шаркі, адресованих молодим, а також мовою молодих. Публічна галузь літературної творчості відрізнялася своєю продуктивністю порівняно з літературною прозою періоду Азербайджанської Демократичної Республіки. Так, «Джаліл Мамедгулузаде», «Азербайджан» [1917], «Республіка» [1917], «Громадяни» та інші публіцистичні праці були зосереджені увагою на суспільно-політичних питаннях. Очолюючи розвиток національних мислительних творів, розроблених незалежними видами, в період Азербайджанської Демократичної Республіки особливу увагу приділяли публіцистичним зразкам, які послідовно публікували в різних пресах. Коротше кажучи, народна боротьба за свободу розширювалася. У зв'язку із цим виникла потреба в більшому використанні можливостей висловлення публіцистичного слова. Відображено низку аспектів суспільно-політичного життя початку XX століття, описано трагедію з можливістю літературного вираження в документальних оповіданнях Сеїда Хуссейна «Ісмаїлія» та «Меланхолійна пам'ять». В оповіданні «Ісмаїлія», яке грунтувалося на виступі автора, йдеться про спалення душі болю великої знаменитої споруди Ісмаїлії вірменами. Драматичні твори, написані за часів Демократичної республіки, були не стільки, скільки зразками літературної прози. Саме так були створені драматичні твори, що роз'яснюють деякі можливості творів історичного періоду. Отже, драматичній творчості Джаліля Маммадгулузаде, Хуссейна Джавіда, Джафара Джаббарлі, Мірзабала Махаммадзаде приділяють більше уваги в цьому плані. Отож твори Джаліла Мамедгулузаде «Каманча», «Книга моєї матері», Хуссейна Джавіда «Насрадін Шах», «Одринський конгрес», «Трабліська війна або зірка» $\mathrm{i}$ «Айдін» детально висловили погляд на драматургію того часу.

Ключові слова: Демократичний республіканський період, літературний процес, літературна проза, поезія, гласність. 